\title{
Organization Culture of Student Council to Shape the Students' Entrepreneurial Trait
}

\author{
Lelahester Rina \\ The Faculty of Teacher Training \\ and Education \\ Sebelas Maret University \\ Surakarta, Indonesia \\ lelahester@student.uns.ac.id
}

\author{
Wiedy Murtini \\ The Faculty of Teacher Training \\ and Education \\ Sebelas Maret University \\ Surakarta, Indonesia \\ wiedymurtini@staff.uns.ac.id
}

\author{
Mintasih Indriayu \\ The Faculty of Teacher Training \\ and Education \\ Sebelas Maret University \\ Surakarta, Indonesia \\ mintasih_indri@staff.uns.ac.id
}

\begin{abstract}
Graduates from Senior High School are often getting less attention towards their entrepreneurial trait skills rather than the graduates from vocational school. This study focuses on the organization cultural phenomenon that emerges in the Student Council members in SMA Kristen Satya Wacana Salatiga when they do entrepreneurship. This entrepreneurship culture refers to the fund raising done by Student Council members to fulfill the targeted amount of fund for running their programs. This study was using qualitative method with domain analysis through seeking the semantic relation from Spradley. They were chosen because of a consideration that they succeeded in their project through a fund raising to get a big amount of money. The data were obtained through observation, documentation, and interview which were done to the Student Council members, Student Council teacher supervisor, vice principal of student department in SMA Kristen Satya Wacana Salatiga. The result of this study showed that organization culture and experience could shape the entrepreneurial trait in Student Council members of SMA Kristen Satya Wacana Salatiga. The emerged entrepreneurial trait were creative, innovative, hard-working, act-oriented, cooperative, communicative, honest, and having a strong motivation to succeed. This study was very important because it could contribute as a reference for Student Council members, teachers, even for the head principal to create an organization culture in school that can support and shape the students' character. This study was limited to the organization culture of Student Council in Senior High School level which will gain different result if it was done in another level of education. The follow up study is expected to analyze the factors in shaping the entrepreneurial trait between levels or in another level of education to create graduates with entrepreneurial trait in this era of 21st century.
\end{abstract}

Keywords-organization culture of student council, entrepreneurial trait, entrepreneurship education

\section{INTRODUCTION}

Education has a very important role in molding students' character $[1 ; 15 ; 25]$. Nowadays, many education institutions are trying their best to seek for learning models that focus on character development and skills for any levels of education. The middle level of education has now been the responsibility of the education institution to equip the students with many life skills to help them when entering the working field. In the survey result of National Labor Force of Central Java Province, there are numbers of jobless graduates from senior high school and vocational school [3]. More ironically, the number of jobless graduates from vocational school is higher, which are 271.828 people, than the number of senior high school graduates, which are 134.036 people. This result shows that the educational institutions are needed to improve the quality of the students' skills to make them ready when entering the working field.

It's not necessarily relevant to compare the senior high school with vocational school's methods in learning anymore. About the image that senior high schools focus more on the pedagogical knowledge only and vocational school focus more on the special skills equipment and the readiness to work. The issue that should be the focus today is to equip every level of education with any opportunities, such as skills and strong character to innovate thing needed in the society. Curriculum today has provided the subject about entrepreneurship. It starts from preschool level until senior high school level, even also in the nonformal education. The expected goal of giving this knowledge about entrepreneurship is that all the graduates from any background of education can have the entrepreneurial spirit and trait [13].

Schools and education system play an important role in developing the entrepreneurial trait of the students [8]. Especially for educational institutions today, they need to reduce the learning process that focuses only on pedagogy, but also to encourage and stimulate students to imagine about entrepreneurship [14]. This is implied, instead of educating students about entrepreneurship, it is more on the process of educating students to be entrepreneurs with the success entrepreneurial traits planted in them [10]. Besides, entrepreneurship education is about teaching students of the theory until the application to understand about entrepreneurship [14]. In this case, students are expected to be creative, innovative, confident, and have a strong motivation to succeed in everything. They will experience working together in a team, communicating with other people, achieving the target with any risks coming, and being creative 
when doing something or even when facing the problems.

Entrepreneurship education supports the shaping of skills, knowledge, and entrepreneurs traits [6-7; 10; 21]. Entrepreneurship education can be done through the opportunity for students to explore their skills. This skill can be shown through the application when the students do anything. Since this method is easier to understand rather than through the knowledge obtained from conversation, discussion, and organization experience [11]. Therefore, students are often lack of idea in creating entrepreneurial opportunities, which leads them to have low quality skills [11].

Entrepreneurship education should be developed and realized in any school activities in order to create the students' entrepreneurial traits. There are some parties that involve in education, such as the policy makers, school administrator, teachers, students, and society [4]. Beside of the school's role, the entrepreneurship traits can also grow through family's role, especially parents, who teach and and invite children to directly involve in any entrepreneurial activities $(18 ; 19]$. The advancement of technology, especially social media nowadays, also plays a role in growing entrepreneurship traits $[9 ; 19 ; 20]$. Schools can apply the entrepreneurship education strategy [5] through: a) Taking cross-disciplinary, b) Interactive learning, c) Involve educational-interest people, d) Curriculum development e) External reach-out (related to business), f) Fund raising ability, g) There is 1 exact measurement for all answers, $\mathrm{h}$ ) Continuous learning.

The goal of entrepreneurship education both learners and graduates in all types and levels of education has an entrepreneurial spirit within them. The Minister of Education and Culture Center for Research and Development of the Curriculum Center divides some of the entrepreneurial characteristics and entities created through entrepreneurship education: independent, creative, risk-taking, action-oriented, leadership, hard work, honest discipline, innovative, responsible, cooperation, unyielding, commitment, realistic, curiosity, communicative and powerful motivation for success [13]. Therefore, the efforts of schools in inculcating the entrepreneurial spirit according to the Ministry of National Education Balitbang Pusat Kurikulum [13] through: integrating all subjects, integrated in extracurricular activities, student self-development activities, learning process, integration in the form of teaching materials, through school culture and process giving local content to all school residents.

One of the opportunities that schools can use to improve the skills and character of students is through practicing school organizing. One of the organizations available is through the Intra School Student Organization (OSIS). Each organization must have some things that become role models and uniqueness compared with other organizations. Beliefs trusted by all members of the organization which is then used as a guide in facing both internal and external problems and are considered to be true according to them are called as organizational culture $(2 ; 17]$. Therefore, the value is not only learned but applied and interpreted by all members [2]. In addition, they will strive to develop value and disseminate what they believe to new members to do the right activities together [16]. Meyer explained that the concept of organizational culture has several elements such as emotional attachment to the institution (affective), sense of obligation to the institution (normative) and must remain with the institution based on the cost incurred [12].

Organizational culture is divided into two schools of thought: ideational school and adaptationist school. Ideational school is a system of open and collective meaning that applies for a certain time to a certain group of people who need to be shared (shared, understood and practiced together) in order to generate shared meaning. Secondly, adaptationist school is a shared belief and value that gives meaning to members of an institution and makes that belief and value as a policy of how to behave in the organization [22]. It can be concluded that organizational culture is a value, attitude, belief, assumption or norm that is believed and has long been agreed and followed by members of the organization and then distributed to new members of the organization.

Characteristics of Organizational Culture according to Robbins are: a) Individual initiative, level of responsibility, freedom or independence that every individual has in expressing opinions. Individual initiatives need to be respected as long as the idea is for promoting and developing the organization; b) Tolerance to risky action, members can act aggressively, innovatively, and take risks; c) Instruction, the organization can clearly create the desired goals and expectations. This is stated in the vision, mission and objectives of the organization; d) Integration, organizations can encourage organizational units to work in a coordinated manner that can create quality and quantity of work; e) Management support, managers can provide communication or direction, assistance and clear support in order to smooth the performance of the organization; f) Controls, controllers are the rules or norms applicable within the organization; g) Identity, members of an organization may identify itself as a unit within a company not a specific professional group that is not a unified organization; h) Tolerance to conflict, members openly expressed conflict and criticism; i) The pattern of communication is limited by a formal hierarchy of authority [24]. Some characteristics of organizational culture can show how important the existence of organizational culture is.

The process of establishing organizational culture according to Deal \& Kennedy describes some elements of organizational culture, namely: a) Business environment, influential in terms of products, competitors, customers, technology, suppliers, government policies; b) Values, basic beliefs adopted by the organization as a guide in 
thinking and acting in achieving organizational goals; c) Heroes, figures considered successful in realizing cultural values in real life d) Rituals, as a recurrent sequence of activities that reveal and reinforce the organization's core values; e) Cultural network, informal communication network as the primary communication channel [24].

Based on some of the elements that have been described, it can be interpreted that several factors are interrelated in order to shape an organizational culture. After looking at some of the elements that make up the organizational culture, the following describes the process of establishing organizational culture by Kotter and Heskett can come from anywhere: from individuals or groups from the lower or top levels of the organization [24]. The process of cultural shaping can be fast and can also gradually instill, grow and develop an organizational culture through leadership style and organizational work climate.

Thus, the researchers tried to base this research with some questions: How is the implementation of organizational culture in Satya Wacana Senior High and Junior High Schools? How is the role of organizational culture in shaping the entrepreneurial spirit of Satya Wacana Christian High School students? The researchers used those research questions as the leading questions for the interview and observation in the research field. The implementation and the culture's role are very important to be studied as the schools' effort to prepare the students to have skills and entrepreneurial spirit in today's era. As the findings, the students' indentities and characters shouls be considered in organizational leadership as a response from this dynamic global environment and technology. Even the leadership in the organzation is the supporting strategy in achieving the success of the students' career in the future.

This study is based on the interesting phenomenon in the Student Council of SMA Kristen Satya Wacana, which is leadership leads to entrepreneurship such as doing fund-raising to host events as the implementation of their organization's work program. The chairman and members have fund-raising initiatives in various ways to make the budget fulfilled. Schools give only a small budget and students must develop it. Courage to take risks by coordinating all members of the intra-school student organization makes this organization quite famous in organizing Lab Cup events in Central Java area. The biggest Lab Cup event was held by inviting junior high school students in order to promote the school in Central Java for basketball competition, dance and cheerleader. The annual events that are done in the students organization create the students' habits that leads to having the entrepreneurial values and practices becomes a culture in the Student Council.

\section{METHOD}

The purpose of this study was to know the culture within the organization of Student Council (OSIS) in SMA Kristen Satya Wacana. The reason why researchers chose SMA Kristen Satya Wacana was that they were selected for the consideration that they succeeded in conducting work programs through fund-raising in order to achieve substantial budget targets. This research was conducted qualitatively to see the organizational culture in entrepreneurship by members of Student Council Organization (OSIS) and entrepreneurial activities by all members. Technique of selecting the research subjects was using purposive sampling technique through snowball sampling. The data collection in determining the source of the participants will invoke the recommendations of the researcher's subjects to show who has the information and understand the central phenomenon. The informants in this study include members and administrators of OSIS, OSIS counterparts, principals, vice chief of SMA Kristen Satya Wacana and some other school residents related to OSIS's activities. This research data were obtained from observation, documentation and interviews to informants who were considered knowing the information and phenomena that existed. This research used domain analysis technique from Spradley. Spradley divides the stages in domain analysis, which are: a) choosing the semantic relation pattern, b) preparing the domain analysis worksheet, c) selecting the similarities from the informants' statements based on the interview transcript and participation observation, d) seeking the covering and covered terms which correlate with the semantic relation, e) listing the structural questions for each domain, f) making the identified domains list [23].

\section{RESULT}

Based on the results of research, there found some findings about the shaping of organizational culture in Student Council of (OSIS) SMA Kristen Satya Wacana in growing the entrepreneurial spirit of students. Data were divided into several domains, such as: 1) the function of the shaping of organizational culture, 2) the implementation requirements of organizational culture, 3) organizational culture implantation, 4) the shape of the integrated organizational culture implementation, 5) the result of the process of shaping organizational culture. As in each domain, there are findings of relevant sub-domains to support the research data. The following presents the domain analysis of organizational culture profile at Student Council of SMA Kristen Satya Wacana (OSIS): 
TABLE 1. Domain Analysis of "Organizational Culture Profile in the Student Council of Satya Wacana Christian Senior High School"

\begin{tabular}{|c|c|c|c|c|}
\hline No & Sub domain details & $\begin{array}{l}\text { Semantical } \\
\text { Relation }\end{array}$ & Domain & Evaluation \\
\hline \multirow[t]{2}{*}{1} & $\begin{array}{l}\text { a) Continuing the previous } \\
\text { OSIS activity }\end{array}$ & Is the function of & $\begin{array}{l}\text { Organizational } \\
\text { culture shaping }\end{array}$ & \multirow[t]{2}{*}{$\begin{array}{l}\text { What are the functions of shaping } \\
\text { the organization culture }\end{array}$} \\
\hline & $\begin{array}{l}\text { b) Giving the opportunity to } \\
\text { serve and improve }\end{array}$ & & & \\
\hline \multirow[t]{2}{*}{2} & $\begin{array}{l}\text { a) Environment that supports } \\
\text { entrepreneurship }\end{array}$ & \multirow[t]{2}{*}{$\begin{array}{l}\text { Is the requirement } \\
\text { from }\end{array}$} & \multirow{2}{*}{$\begin{array}{l}\text { Implementing } \\
\text { organization } \\
\text { culture }\end{array}$} & \multirow{2}{*}{$\begin{array}{l}\text { The suitability of the environment } \\
\text { and the opportunities students get } \\
\text { with the facts in the field }\end{array}$} \\
\hline & $\begin{array}{l}\text { b) Open-minded to accept } \\
\text { values }\end{array}$ & & & \\
\hline \multirow[t]{5}{*}{3} & $\begin{array}{l}\text { a) Committees in any OSIS } \\
\text { activity program }\end{array}$ & \multirow[t]{5}{*}{ Is/are the shape of } & \multirow{5}{*}{$\begin{array}{l}\text { Implementing the } \\
\text { integrated } \\
\text { organization } \\
\text { culture }\end{array}$} & \multirow{5}{*}{$\begin{array}{l}\text { The suitability of organization } \\
\text { culture implementation obtained by } \\
\text { the students from the facts in the } \\
\text { field. }\end{array}$} \\
\hline & b) Leaning process & & & \\
\hline & c) Teacher's assistance & & & \\
\hline & d) Socializing and training & & & \\
\hline & $\begin{array}{l}\text { e) Extracurricular and routine } \\
\text { activities }\end{array}$ & & & \\
\hline \multirow[t]{3}{*}{4} & a) Entrepreneurial students & \multirow[t]{3}{*}{ Is the result of } & \multirow{3}{*}{$\begin{array}{l}\text { Shaping the } \\
\text { organization } \\
\text { culture }\end{array}$} & \multirow{3}{*}{$\begin{array}{l}\text { The conformity of the result of } \\
\text { organization culture shaping in } \\
\text { OSIS with the facts in the field. }\end{array}$} \\
\hline & $\begin{array}{l}\text { b) Understanding of } \\
\text { organization vision }\end{array}$ & & & \\
\hline & c) Have a serving attitude & & & \\
\hline
\end{tabular}

For the pattern of semantic relationships listed in table 1 , the researcher also makes the work pattern of domain analysis as shown in Figure 1 which is about the establishment of organizational culture in SMA Kristen Satya Wacana to foster the entrepreneurship spirit of the students. The following presented the work pattern of domain analysis work is, as follows:

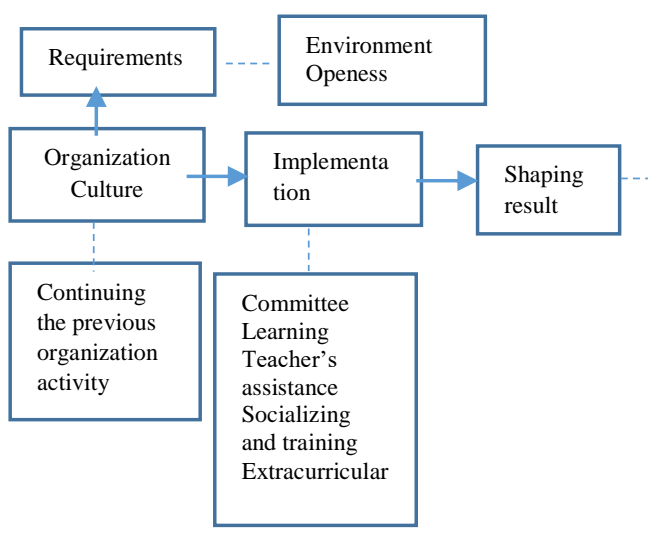

Fig. 1. Work Pattern of Domain Analysis

\section{A. Organizational Culture Shaping}

Organizational culture has a role as a guide in conducting organizational activities according to the values held by all members of Student Council Organization (OSIS). The Student Council (OSIS) of SMA Kristen Satya was formed through the experience of previous organizational council members who then applied in their new organization: "I thought that learned from the experience, they say when their seniors prepared, OSIS must experience regeneration. When they do not join yet, they will watch the effort, and when they enter, they will refer to the previous generation of OSIS" (S-DW.12). The effort to recognize the value and experience passed by the members of OSIS makes them understand the business and problem solving when facing problems. Culture is shaped through the planting of values believed by the previous OSIS management to their juniors, so that when the reorganization, the new board members understand the situation and program activities and handling or treatment that must be done.

\section{B. Organizational Culture Requirements}

The phenomenon of Student Council (OSIS) of SMA Kristen Satya Wacana happened because of the responsibility of the board in implementing their work program. There are several opportunities provided by schools, such as financial support, school-tolerance when member of the OSIS undertakes the fund raising to achieve the required budget, and the teacher guidance when students experience difficulties: "Division 4 OSIS in cooperative and entrepreneurship sections manages the sales of stationery and food" (S-S.8).

When OSIS organizes school activities in the support of tolerance for them to sell: "For example, the Valentine activity needs funding, school provides support but not it is not enough, that's why we need to work through fund raising both inside and outside the school through submitting proposals to companies or stores" (S-S.9). Support from OSIS teacher of entrepreneurship section is also given to the students through the offering of capital loan: "I, as the supervisor of the division 4 entrepreneurship, always bring money, so if they they need capital, they can borrow from me, but if they have recollected the money, they can return it. But in fact, sometimes they try to make their own capital, sometimes they also ask 
for my suggestion if they want to raise fund with some products, such as how if we sell this, etc" (S-S.10).

The form of responsibility undertaken by members of the OSIS can be seen in their efforts to solve the problems encountered i.e. creative ideas for funding to meet the budget for OSIS program. The coordination and similarity of objective is done by the chairman of OSIS and the other managements so that the fund rising runs smoothly. There are even some high school students who took advantage of cooperative opportunities by entrusting food for sale in the cooperative: "many students come and entrust their foods, such as takoyaki, pizza” (S-NS.5).

Thus, characters such as responsibility, risk-taking, creative and innovative, cooperation among members of the OSIS appear when they do certain activities: "The committee is divided into some parts for taking turn doing the fund raising, so it is not only the job of fund raising section members but also all of the committees" (S-OA.16). Not only happened to members of OSIS but also entrepreneurship activities are also felt and applied by other students in addition to members of the OSIS. Thus, the openness toward values are developed through the involvement of all members of the OSIS becomes a requirement for the emergence of organizational culture. High enthusiasm in the fulfillment of duties and responsibilities becomes the key to acceptance of values that are formed unconsciously.

\section{Implementation Shaping of Organizational Culture}

The implantation of values contained within the organization, especially in the Student Council of SMA Kristen Satya Wacana is formed from the implementation of school activities. One of the main activities that provide the understanding about responsibility, cooperation, dare to take risks is through the involving-as-committee activity: "we, from OSIS, will start from now on (one month before the event is held) to shape a committees for some events, such as Valentine Day and Easter Day, but for our biggest event, Lab Cup, we should actually form the committee long before the d-day" (S-PK.6). "OSIS events consist of: Valentine Day, Kartini Day, Easter, Camping, Live in, Prom Night, Lab Cup, Christmas, Independence Day, New Students Orientation, Students Basic Leadership Training, Creative Day, Month of Language, Classmate, Welcoming Party for New Comers, Social Service, OSIS Democracy Celebration” (S-PK.14).

Of those several programs of OSIS activities, there are quite a lot of activities in a year to be held by OSIS with some effort and hard work of all members. Coordination and implantation of organizational culture is shaped through this role, as each activity has different committees and different responsibilities experience according to the field.
There is even one event that provides opportunities for students in addition to members of the OSIS involved in committees such as Lab Cup: "This such activity is aimed to train the next generation of OSIS" (S-PK.8).

One of the forms of organizational culture implementation is through the learning activities of Workshop and Entrepreneurship given from grade 10 to grade 12: "Students produce products from Workshop and Entrepreneurship lessons through bazaar and gallery workshops and entrepreneurial activities while taking class report cards. Then, it has been taught in class XI children catfish cultivation, they are struggling to make a place to nurture, in groups, they look for fish seeds, treat by feeding the fish, into the step of selling the catfish" (S-SJ.3). This has also been supported by the teacher of PKU in PKU learning process: "The learning process in grade XI starts from making fish enlargement proposals, proposal presentations, assignment, such as fish enlargement guidelines, pond planning, fish release to ponds, and caring for fish until waiting for the harvest time. Their final projects are harvesting and selling fish, such as catfish and indigo, the enlargement process is also reported in the form of videos that are uploaded to the internet via YouTube" (S-DJT.2).

In addition, based on the observations made by researchers, that grade 10 has a craft cultivation practices from the used materials and ornamental plant cultivation, while the class 12 has a traditional food processing. The opportunity to work in learning gives meaning to the implantation of values in students to be able to have entrepreneurial spirit such as starting from having a creative idea to create product, cooperating with group, being honest in making product and reporting and other entrepreneurial characters that generating attitude of success-oriented.

Activities in the implementation of organizational culture are shaped through teacher assistance to students but this is only a passive assistance: "If you can be honest, OSIS SMP and OSIS SMA is very different. If OSIS SMP the teachers are still holding the students' hands, schools and funds obtained also more than the funding so it is still easy. While the high school OSIS was very much different and more mental test also funds from the school a little more so should be extracting more hard work" (S-PK.18). In addition, the very party who played the role of OSIS was the deputy head of the student: "All are taken care of by the students but no consultation with students, either allowed or forbidden advice with certain considerations" (S-DW.10). The independence created by the higher level of education allows members to assume that the responsibilities they carry are heavier and must be able to complete 
the program of OSIS activities. Teacher assistance is also gained by members of the organization through stimulating teachers to be creative, train courageous speaking in front of the crowd and train their confidence and character planting.

Strengthening the achievement of organizational goals conducted by members of the OSIS can also be obtained through socialization and training, such as: Basic Leadership Training Students are given specifically to members of OSIS, the New Student Orientation Period through entrepreneurial activities as the stock of entrepreneurship experience and entrepreneurial character: "School has Basic Leadership Training Students to be given to school OSIS administrators, which is organized by providing external speakers." (S-S.24). The culture of the entrepreneurship can also be shaped through the extracurricular activities, such as Boy Scouts: "Scouting activity (or Lab School Scot) in its activities implanted nationalist carpenter and entrepreneurial character ... is indirectly done" (S-SK.15).

\section{Result of Shaping of Organizational Culture}

As previously stated, the organizational culture at OSIS is shaped through various activities and support provided by the school. In every effort through every work program of OSIS, all members are given a good understanding by the board or the school. Through the experience and observation of previous OSIS management, there is an understanding to the management of the entrepreneurship values as the basic for conducting OSIS activities. The lack of funds generates creative ideas for fundraising: "... in terms of funds, we have the biggest event which is Lab Cup that takes tens of millions of rupiah and which the students will look for the money and school only provides some. The students consult with the creative teacher to fulfill the activity, so that they are entrepreneur by communicating e.g. submitting proposal to the company. In addition, they sell things either with their own capital or capital loan from parents but sometimes they also borrow from the student cooperative." (S-DW.11). Some shapes of fund business starting from proposal submission, live music, food, beverages, clothes, chocolate valentine, even based on the observation of the teacher that the organizational culture i.e. entrepreneurial spirit appears when students have graduated from school and continue to higher education they continue the effort to extract funds meet their activity budget. The establishment of an entrepreneurial spirit is formed on the members of the co-operative OSIS: "Cooperatives and entrepreneurship they manage the sales of stationery as well as food and snacks. I think that's where they learn entrepreneurship." (S-S.8).

All OSIS activities programs make all members of OSIS responsible for their respective fields to achieve their organizational goals. The opportunity to lead the activities either through coordinating with the committee members, participants of students, teachers and staff of school staff shape their developing leadership. Commitment before becoming an OSIS board also serves as a basis for them to serve in their activities and even hard work so that every event can be successfully implemented.

\section{DISCUSSION}

This study reviews the organizational culture of Student Council (OSIS) in SMA Kristen Satya Wacana. The research findings show that the organizational culture in OSIS activities fosters their entrepreneurial spirit. This can be seen in the effort and hard work of members of OSIS in solving the funding problems to meet the budget of organizing certain activities. Although schools continue to stimulate some of the funds for their activities, all the board and members of OSIS have a firm belief that one of the keys to the successful implementation of activities is supported by the extraction of funds. Reference [5] explained that about strategies that can be done by the organization through entrepreneurship education are: external outreach (related to business), fundraising ability and continuous learning. This is seen when schools also provide support through school environments that support students in fundraising.

In addition, the results of the study also show that organizational culture is shaped through integrated opportunities by the direct involvement of members of the OSIS in the committees. This is in line with Kotter and Heskett explained that organizational culture can come from anywhere: from individuals or groups from the bottom or top level of the organization [24]. Creative and innovative in creating opportunities through understanding by leaders and members of the previous OSIS is the reason of the organizational culture is shaped. However, the findings in this study are organizational culture shaped through the experiences of previous organizations that internalize and teach them to have enthusiasm and entrepreneurial spirit. School institutions should not be focused on pedagogical activity only, but also should encourage and stimulate learners to imagine about entrepreneurship [14]. The purpose here is to educate not only about how to create entrepreneurship but also to have entrepreneurial traits within them [10]. One shape of cultural implementation also occurs through the environment, values, basic beliefs adopted by the organization as a guide in thinking and acting in achieving organizational goals, cultural networks, and informal communication networks [24]. This has been done based on the results of research that is through a supportive school environment, the value of 
cooperation and responsibilities they are in accordance with their duties and have a network to deliver their fund raising proposals to the fund sponsorship.

Minister of Education and Culture Center for Research and Development of Curriculum Center describes the entrepreneurial spirit that needs to be considered and can be shaped from the existence of organizational culture such as: independent, creative, risk-taking, action oriented, leadership, hard work, honest discipline, innovative, responsible, cooperative, unyielding, committed, realistic, curiosity, communicative and powerful motivation for success [13]. Based on the results of research, organizational culture shapes the entrepreneurial spirit in the members of OSIS in SMA Kristen Satya Wacana. Some of these characters arose when the value creation process in the organization and their responsibilities in the program activities of OSIS. Creative, innovative ideas are shaped when they are able to create an entrepreneurial opportunity to raise funds for their activities that are arguably very much needed. Hard work can be done through capital loan search efforts, submission of proposals, sales of accessories, food and beverages to residents of the school as well as outside the school environment. These responsibilities are characterized by their initiative without the teacher even coordinates either to the committee or to other parties involved in the activity. The other entrepreneurial spirit is the achievement of the goal of the activity cannot succeed without cooperation between members and communication can run as expected. The honest attitude to help each other and work according to their duties and responsibilities characterizes the OSIS organizational culture in SMA Kristen Satya Wacana.

\section{CONCLUSION}

This paper explores the organizational culture and results of organizational culture in the Student Council of SMA Kristen Satya Wacana Salatiga. The results of this study indicate that the organizational culture is shaped through the experience and understanding of the values provided by accident to the next generation, in this case new members of the OSIS. As a support for OSIS to carry out all of the OSIS activities, school as an institution that oversees the organization provides a supportive environment, support and guidance of the parties involved such as escort teachers and deputy head of student division. Besides, the shape of the implementation of organizational culture is done through the involvement of members in the committees, the integration in the learning process, socialization/training and extracurricular which is done by members of the OSIS. The result of this organizational culture fosters the entrepreneurial spirit to the students because of the speed and opportunity of the activities that become their way out in solving the funding problem so that the activity program objectives are achieved. These findings provide suggestions to schools to create an organizational culture within the school environment and support all their opportunities to create creative ideas, cooperation among members of OSIS or others to achieve their goals of activities, initiatives to create student independence, honesty and responsibility to arise within them when they are doing the activities of OSIS.

However, this study has limitations in terms of the scope of research which only takes participants of the OSIS members because the researchers want to see their organizational culture. Therefore, it implies further research to review the organizational culture of students in developing their entrepreneurial spirit with a wider scope. In addition, further researchers can also use quantitative and qualitative methods in accordance to the phenomenon of organizational culture and issues of entrepreneurial spirit and entrepreneurship education in schools.

\section{ACKNOWLEDGMENT}

The researcher would also like to say thank you to Master Program in Economics Education of Universitas Sebelas Maret for the never ending support along the researcher's study process, also to Economics Education Study Program, Faculty of Teacher Training and Education, Satya Wacana Christian University for the suport through funding in the advanced study and research publication.

\section{REFERENCES}

[1] E. Andayani, L. Srihariani, S. Winarsih and Rusno, "The contribution of school's characters to the effectiveness of entrepreneurial learning based on local wisdom," International Journal of Pedagogy and Teacher Education, vol. 1(1), pp. 37-45, 2017.

[2] P. M. Ate, "Budaya organisasi sekolah dalam meningkatkan kinerja guru," Jurnal Pendidikan Humaniora, vol. 2(4), pp. 391-400, 2014.

[3] Badan Pusat Statistik Jawa Tengah. https://jateng.bps.go.id/

[4] V. Bikse, I. Riemere, and B. Rivza, "The improvement of entrepreneurship education management in latvia," ProcediaSocial and Behavioral Sciences, vol. 140, pp. 69 - 76, 2014.

[5] E. V. Bindah, and H. A. E. Magd, "Teaching entreprenenurship in oman: successful approaches." Procedia-Social and Behavioral Sciences, vol. 219, pp. $140-$ 144, 2016.

[6] A. D. Daniel, R. A. Costa, M. Pita, and C. Costa, "Tourism education: what about entrepreneurial skills?," Journal of Hospitality and Tourism Management, vol. 30, pp. 65-72, 2017.

[7] B. H. Din, A. R. Anuar, and M. Usman, "The effectiveness of the entrepreneurship education programing upgrading entrepreneurial skills among public university students," Procedia - Social and Behavioral Sciences, vol. 224, pp. 117 $-123,2016$.

[8] A. B. Ibrahim, and K. Soufani, "Entrepreneurship education and training in canada: a critical assessment," Education +Training, vol. 44(8/9). Pp. 421-430, 2002.

[9] F. E. Indoworo, "Menumbuhkan jiwa wirausaha melalui peran sosial media," Jurnal Informatika UPGRIS, vol. 2(1), pp. 45-55, 2016.

[10] V. Y. Ismail, E. Zain, and Zulihar, "The portrait of entrepreneurial competenceon student entrepreneurs," Procedia - Social and Behavioral Sciences, vol 169, pp. $178-$ 188, 2015. 
[11] S. L. Jack and A. R. Anderson, "Entrepreneurship education within the enterprise culture: producing reflective practitioners," International Journal of Entrepreneurial Behavior \& Research, vol. 5(3), pp.110-125, 1999.

[12] A. K. Jain, "Volunteerism and organisational culture: relationship to organizational commitment and citizenship behaviors in India," Cross Cultural Management, vol. 22(1), pp.116-144, 2015.

[13] The Minister of Education and Culture Center for Research and Development of the Curriculum Center, "Bahan pelatihan penguatan metodologi pembelajaran berdasarkan nilai-nilai budaya untuk membentuk daya saing dan karakter bangsa (pengembangan pendidikan kewirausahaan)," Jakarta: kepala pusat kurikulum, 2010.

[14] D. A. Kirby, "Entrepreneurship education: can business schools meet the challenge?," Education + Training, vol. 46(8/9), pp. 510-519, 2004.

[15] N. Komariah, and Rohana, "Peran wakil kepala sekolah bidang kesiswaan dalam meningkatkan disiplin siswa di Sekolah Menengah Atas (SMA) Muhammadiyah Tembilahan," Jurnal Al-Afkar, vol 3(2), pp. 79-143, 2015.

[16] Kusdi, "Budaya organisasi: teori, penelitian, dan praktik," Jakarta: Salemba Empat, 2011.

[17] Manshur, "Penerapan sistem nilai dalam budaya organisasi sekolah unggul: studi multikasus, "Jurnal Pendidikan, vol. 31(3), pp. 512-523, 2012.

[18] M. A. Ningrum, "Peran keluarga dalam menumbuhkan jiwa wirausaha sejak usia dini," Jurnal Pendidikan, vol. 2(1), pp. 29-32, 2017.

[19] Rokhimah and Margunani, "Pengaruh pendidikan kewirausahaan dan lingkungan keluarga terhadap jiwa kewirausahaan siswa akuntansi smkn 1 demak tahun 2016," Economic Education Analysis Journal, 6(2), 559-570, 2017.

[20] A. Rubens, G. A. Schoenfeld, B. S. Schaffer, and J. S. Leah, "Self-awareness and leadership: developing an individual strategic professional development plan in an mba leadership course," The International Journal of Management Education, vol. 16, pp. 1-13, 2018.

[21] V. B. Sanchez and C. A. Sahuquillob, "Entrepreneurial intention among engineering students: the role of entrepreneurship education. European Research on Management and Business Economics, vol. 24(1), pp. 53-61, 2017.

[22] A. Sobirin, "Budaya organisasi: pengertian, makna dan aplikasinya dalam kehidupan organisasi," Yogyakarta: Sekolah Tinggi Ilmu Manajemen YKPN, 2009.

[23] J. P. Spradley, "The ethnographic interview. United Stated: Waveland Press, Inc, 2016.

[24] M. P. Tika, "Budaya organisasi dan peningkatan kinerja perusahaan," Jakarta: PT Bumi Aksara, 2014.

[25] L. Winarsih, and Warsono, "Strategi pembinaan karakter anggota ekstrakurikuler kelompok ilmiah remaja (kir) SMA negeri 1 badegan Ponorogo," Kajian Moral dan Kewarganegaraan, vol. 5(2), pp. 193-207, 2017. 